\title{
仙台市西方, 安達火山噴出物のストロンチウム同位体比
}

Strontium isotope ratios of the products from the Adachi volcano, Northeast Japan

$\begin{array}{lll}\text { 蟹沢 聰 } & \text { 史 (Satoshi Kanisawa)* } \\ \text { 柴 田 } & & \text { 賢 (Ken Shibata)** }\end{array}$

The Adachi volcano situated to the west of Sendai, Northeast Japan is assumed to be the source of the Adachi-Medeshima pumice belonging to the Late Pleistocene. Strontium isotope ratios of four samples of the products of the Adachi volcano were determined. The determined rocks are 1) fresh and white pumice (cummingtonite dacite), 2) cummingtonite dacite (lithic fragment), 3) leucocratic cummingtonite tonalite (lithic fragment), 4) hornblende bearing cummingtonite tonalite (lithic fragment). ${ }^{87} \mathrm{Sr} /{ }^{86} \mathrm{Sr}$ ratios of all the rocks fall within a narrow range between 0.70435 and 0.70447 . The results obtained in the present study support an assumption that these rocks are co-genetic in origin.

\section{1.まえがき}

仙台市拉よび名取市西方の新第三系からなる丘陵地 帯と下末吉面に相当する台の原段丘を覆う愛島軽石 （愛島火山灰・愛島テフラ）は降下軽石堆積物からなり, その噴山時代は段丘面の対比から後期更新世之考鼻ら れている(中川ら，1960)。愛島軽石の噴出源は，軽石 層の分布域と層厚の変化，軽石粒括よび石貎岩片の平 均最大粒径の変化から, 模式地の名取市愛島の西方拉 よそ $18 \mathrm{~km}$ の宮城県川崎町安達付近と推定された。さ らに，この軽石層中の石質岩片には基盤岩に由来する ものの他に, 極端比 $\mathrm{K}_{2} \mathrm{O}$ に之しいトーナル岩類が存在 し，その鉱物組み合わせと造岩鉱物の組成が軽石とほ とんど同一であることから，成因的には互いに関連あ るもの之考克ら机ている(蟹沢，1985)。むた，愛島軽 石の噴出源がほぼ明らかになったので，その地名から 新たに『安達火山」と命名され, 従来の愛島軽石は噴 出源の地名々模式地の名前を併記した二重命名法によ り，「安達一愛島軽石」之改称された（蟹沢ら，1986）。 第 1 図に安達火山の位置を示す。今回は, 安達一愛島軽 石，扣よびその中に含李れる本質岩片と考学られるデ イサイト岩片と $\mathrm{K}_{2} \mathrm{O}$ にそしいトーナル岩岩片のスト ロンチゥム同位体比の測定を行ったので報告する。

\section{2. 岩石の記載}

すでに報告したように, 安達一愛島軽石はデイサイト 質で苦鉄質鉱物としてカミングトン閃石のみを含むの が特徵で，その他に石英・累帯構造が著しくコアで An80 越す斜長石・磁鉄鉱・チタン鉄鉱などからな る。噴出源付近の軽石は白色で，非常に新鮮であるが， 噴出源から数 $\mathrm{km}$ 離れた地域の軽石は風化して黄白色 になっている。

この他に，少量ではあるが，本質岩片と考吝られる カミングトン閃石デイサイトがみられ，このデイサイ 卜の鉱物組み合わせと組成は軽石之ほぼ同一である。 安達一愛島軽石もデイサイトも苦鉄質鉱物として斜方 輝石あるいは単斜輝石を含まない。むたここれらのデ イサイト質軽石拈よびデイサイトの主化学組成は東北 地方の他の更新世後期のデイサイト類の組成(青木ら, 1984）とはぼ同じで $\mathrm{K}_{2} \mathrm{O}$ に之しい性質を持つ。

$\mathrm{K}_{2} \mathrm{O}$ K乏しいトーナル岩質岩片は，明らかに基盤花 南岩類や第三紀火山岩類とは異なった性質を持ち， $\mathrm{K}_{2} \mathrm{O}$ を $0.1 \%$ 程度あるいはそれ以下しか含まない。す た, $\mathrm{Rb}$ 当 $1.3 \mathrm{ppm}$ あるいはそ机以下と著しく低い。第 2 図に軽石，石質岩片としてのデイサイト拈よびト一 ナル岩の $\mathrm{Sr}-\mathrm{Rb}$ の関係を示す。トーナル岩質岩片はデ イサイト岩片より量的にははるかに多い。ミアロリ
* 東北大学教養部地学教室 干 980 仙台古川内

** 工業技術院地質調查所 干 305 茨城県筑波郡谷田部町束 1-1-3
(昭和 61 年 12 月 8 日受付 昭和 61 年 12 月 22 日受理 


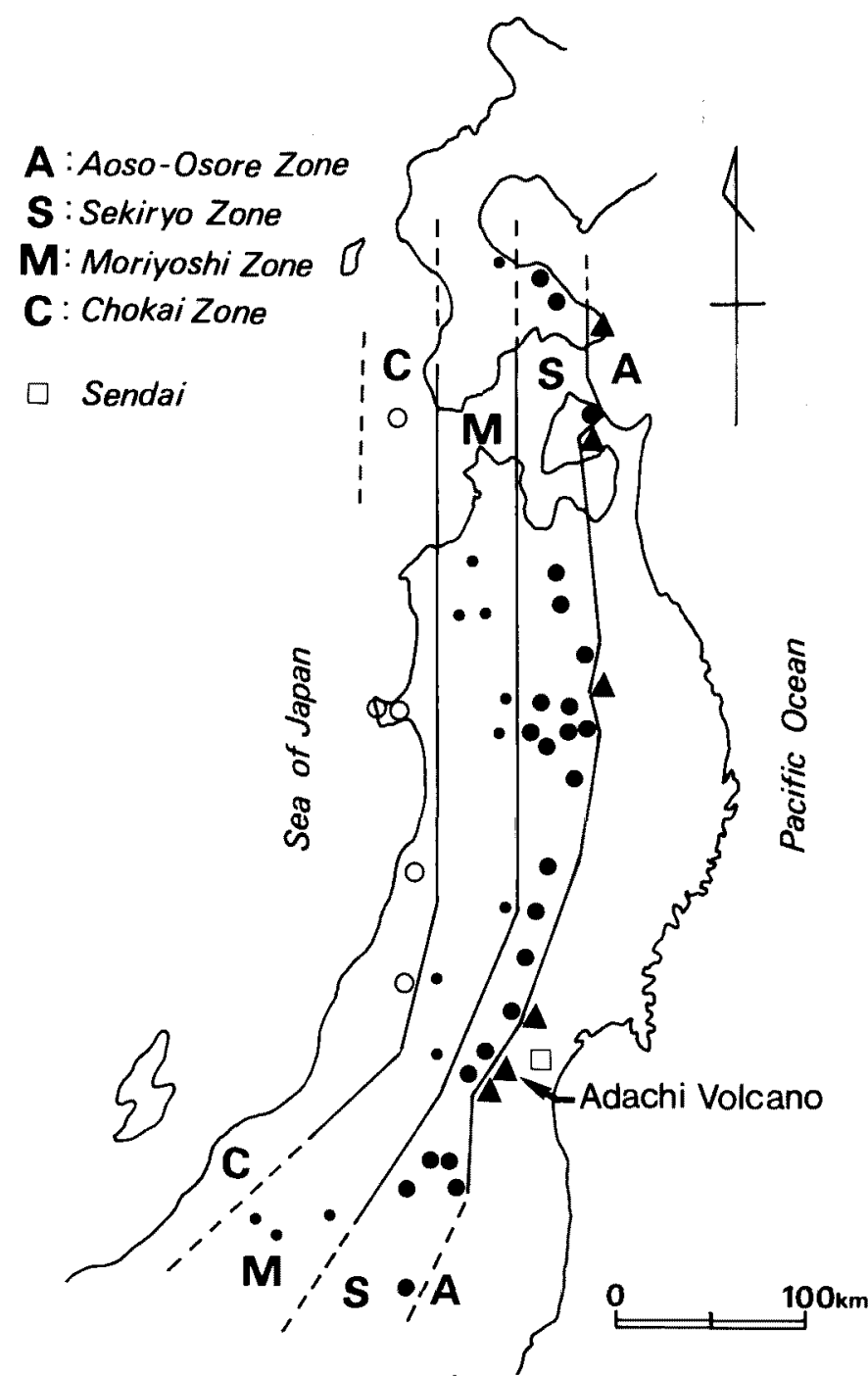

第 1 图 安達火山の位置と東北日本の第四紀火山の带状配列（中川5，1986）。

チック空吵がみられる。最も普通にみられる鉱物組み 合わせは斜長石一石英一カミングトン閃石一鉄鉱物 (磁鉄鉱十チタン鉄鉱)で，その量比扣よび粒度は広い 範囲で変化する。他に，燐灰石，ジルコンなどが少量 存在寸る。細粒でやや斑状を示与すのから, $10 \times 40 \mathrm{~mm}$ 程の粗粒のカミングトン閃石を含み, キュムレイト様

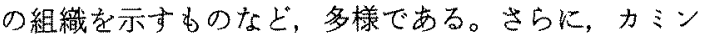
グトン閃石に加えてホルンブレンドをわずかに伴らす のがあり，この場合はカミングトン閃石の中に含まれ ている。カミングトン閃石は自形を呈し，斜長石のコ アの部分には含まれることはなく，周辺部には包有さ れることがある。李た，鉄鉱物は自形を呈し，やはり
斜長石のコアには含まれないが，カミングトン閃石中 には包有される。ホルンブレンドが苦鉄鉱物の主体を なす場合もありこのような岩石は比較的細粒である。 斜長石の累帯構造は軽石やデイサイトのそれとほぼ同 様で,コアの部分はAn80 以上であり, 周辺部はAn3260 程度となっていて，コアと周辺部との間には著しい 組成間譩が認められる。カミングトン閃石の $\mathrm{mg}$-值は 0.63-0.68で，かなり Mgに富む。軽石やデイサイト中 のbのでは，それぞれ 0.62-0.64,0.63であるから，そ れと比較するとわずかに $\mathrm{Mg}$ に富む傾向がある。ト一 ナル岩もやはり軽石やディサイト岩片と同様斜方輝石 や単斜輝石を含まない。また，比較的稀ではあるが董 


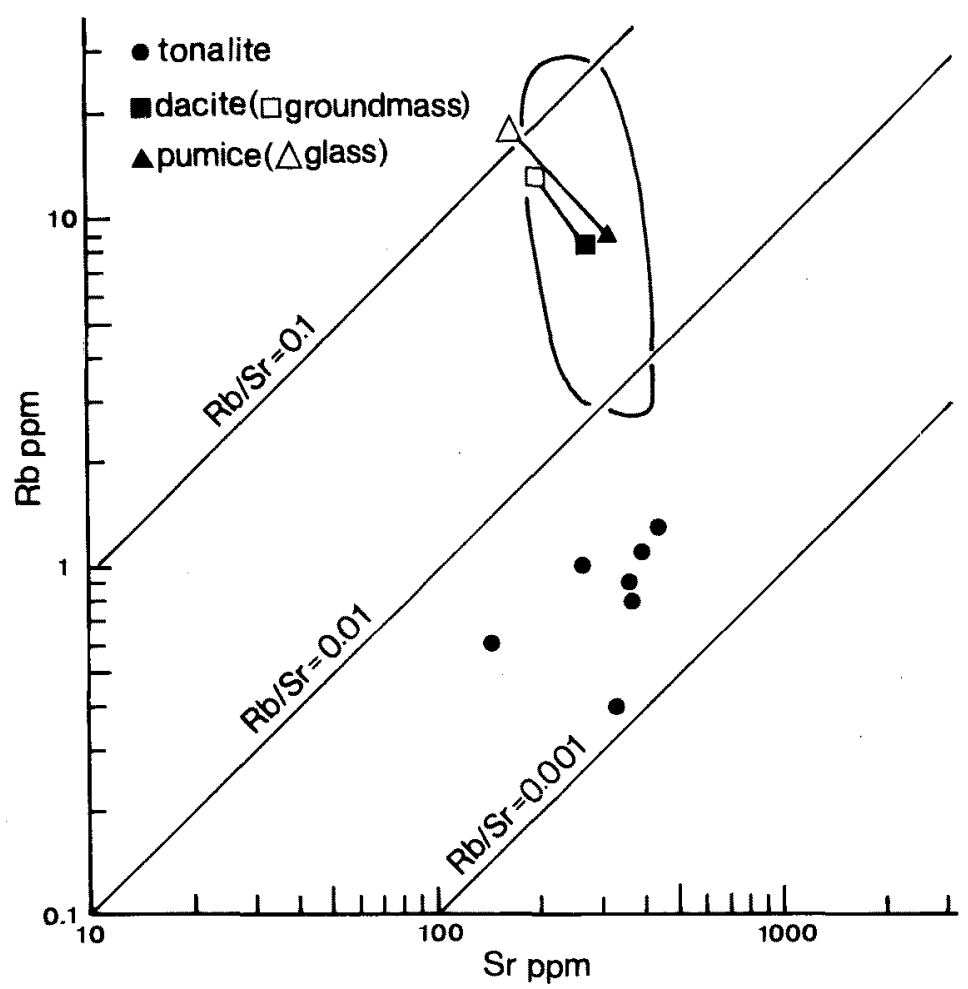

第 2 図 安達火山噴出物の Sr-Rb 関係。曲線で囲んた部分は「青麻一忈火山列」の範囲（霜鳥ら，1983；石 川ら，1985; 富慗ら，1986による)。

青石を含む岩石があり，さらにこのような岩石ではご く少量ながらルチル，スビネルや紅柱石を含むことが ある。薫青石を含む岩石は石英に富んでいる。

\section{3. ストロンチスム同位体比}

分析に用いた試料は次の 4 個である。

1. 安達一愛島軽石(試料番号 No. Adachi-2; 産地 宮城県川崎町安達, 採石場跡) カミングトン閃石ディ サイト。

2. 石質岩片（試料番号 No. 84121501 ; 産地 宮城 県川崎町本砂金，阿光工業採石場）カミングトン閃石 デイサイト。

3. 石質岩片 (試料番号 No. Adachi-7 ; 産地 宮城 目川崎町安達, 採石場跡)優白質カミングトン閃石トー ナル岩。

4. 石質岩片（試料番号No. 84070303 ; 産地 宮城 県川崎町安達一本砂金間の道路沿い)ホルンブレンド含 有カミンク゚トン閃石トーナル岩。

ストロンチウム同位体比の測定は地質調査所のVG Isomass $54 \mathrm{E}$ 型質量分析計を用いて行った。測定誤差

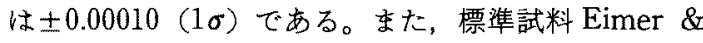
Amend $\mathrm{SrCO}_{3}$ のくり返し測定の結果は $0.70808 \pm$ $0.00002(1 \sigma)$ である。測定結果は第 1 表に示すとおり である。なお，Srおよび Rbの定量は東北大学理学部 核理研の電子ライナックを利用し，光量子放射化分析 法で行った（蟹沢ら，1986）。

この結果から明らかなことは, 白色軽石でやや ${ }^{87} \mathrm{Sr} /{ }^{86} \mathrm{Sr}$ 比が高いが，いずれる 0.7044 付近に集中し， この 4 試料の間では有意の差がないことである。東北 日本の第四紀火山岩の ${ }^{87} \mathrm{Sr} /{ }^{86} \mathrm{Sr}$ 比は, 倉沢 (1975), Notsu (1983), Togashi et al. (1985), 拉よび會沢ら （1986）によって発表されているが，那須火山帯では 0.706 0.703の範团に入り，西南日本のそれよりも一 般に低いこ之，東北日本弧では東から西に向かってこ の比が低くなっていること, 鮮新世後期一更新世初期 に活動した大量の流紋岩，およびそれに関係した火山 岩の ${ }^{87} \mathrm{Sr} /{ }^{86} \mathrm{Sr}$ 比は時代や化学組成によらず， 添一 定の低い值 (0.7038-0.7046) を示すことなどが明らか にされている。安達火山に最も近い春梁火山列（中川 ら，1986）の蔵王拈よび船形火山の安山岩～玄武岩で 
第 1 表 ストロンチウム同位体比括よび $\mathrm{Sr}$ と $\mathrm{Rb}$ の存在量

\begin{tabular}{lccc}
\hline Sample No. & ${ }^{87} \mathrm{Sr} /^{86} \mathrm{Sr}$ & $\mathrm{Sr}(\mathrm{ppm})$ & $\mathrm{Rb}(\mathrm{ppm})$ \\
\hline Adachi-2 & 0.70447 & 312 & 9.0 \\
84121501 & 0.70437 & 272 & 8.6 \\
Adachi-7 & 0.70437 & 396 & 1.1 \\
84070303 & 0.70435 & n.d. & n.d. \\
\hline
\end{tabular}

はをれぞれ0.70384-0.70464 おちよ゙ 0.70407-0.70425 $a^{87} \mathrm{Sr} /{ }^{86} \mathrm{Sr}$ 比が報告されて和り(Notsu，1983)，安達 火山噴出物の值はこれよりやや高い。ただし，倉沢ら （1986）の船形火山の範囲には入る。一方，安達火山の 基盤之考えられるるのは，付近の地質おょび岩片の種 類から判断して，第三紀中新世の烓積岩・火山岩・同 砕屑岩などと阿武幔山地の延長と考えられる花崗閃緑 岩類である。阿武德山地の ${ }^{87} \mathrm{Sr} /{ }^{86} \mathrm{Sr}$ 初生比と現在比 はそれでれ，0.7049-0.7063 (有実型のみ0.7041)， 0.7046-0.7127(丸山，1979)，あるいは0.7047-0.7058， 0.7055-0.7085を示し (Shibata and Ishihara, 1979), 本地城に最も近い宮城県丸森地域の北部阿武隈山地花 崗岩類の初生比は 0.70553 および 0.70645 の 2 種類が 認められる（柴田，1987）。今回のトーナル岩の值は 0.70437-0.70435を示し、デイサイト拈よ゙軽石の 0.70447-0.70437 值とほぼ同じである。安達火山噴出 物の $\mathrm{Rb} / \mathrm{Sr}$ 比はデイサイトで 0.03 程度, ト一ナル岩

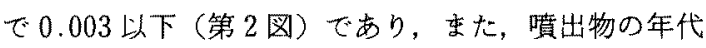
は後期更新世と考えられるので，この同位体測定値は 汪隹初生比をあらおしているとみなしてよい。した がって，デイサイトとトーナル岩とは同位体の面から も同源とみなすことができ，第四紀の完晶質岩である こと，そして阿武隈山地の花崗岩類の一部ではないこ とが明らかである。また，今回測定した同位体比は，鮮 新世後期一更新世初期の大量の酸性火山岩類のそれと ほぼ同じであり，また $\mathrm{K}_{2} \mathrm{O}$ に之しく，贲出量の少ない こと，低温で高酸素分王であった「青森一恐火山列」(中 川ら，1986）の特徵を示す一つのデータとなるである 5 。

謝 辞この研究を行らにあたって，東北大学理 学部青木謙一郎教授, 吉田武義博士, 東北大学教養部 石川賢一博士に日頃からご討論やご協力を頂いてい る。記して感謝する。また，本研究の費用の一部には
文部省科学研究墨補助金（No.59340054）を使用した。

\section{引用文献}

青木謙一郎，吉田武義，金 義沢(1984)，東北地方南 部の更新世前期に活動した火确流の地球化学的研 究. 東北大学核理研研究報告, 17，169-181.

石川賢一，吉田武義, 北川嘉彦，青林謙一郎，大上和 良(1985), 東北本州弧, 岩手県七時雨火山地球 化学的研究. 東北大学核理研研究報告, 18，366378.

蟹沢樆史(1985)，仙台市和よび周辺以分布する受島軽 石とその中の深成岩質岩片について一噴出源の

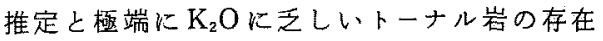
一. 岩鉱, 80, 352-362.

蟹沢聰史, 吉田武義, 青木謙一郎(1986), 仙台市周辺 の安達一愛島軽石，扎よびトーナル岩質石質岩片の 微量成分。東北大学核理研研究報告, 19, 130-138. 倉沢 一(1975), 火山岩の同位体地質学, 火山第 2 集, 20, 307-317.

會沢 一, 藤繩明彦, Leeman, W.P. (1986)，ひとつ の火山に共存するカルク・フルカリおよびソレア イト質岩系マグマーストロンチウム同位体比によ る検討一。地留雑，92，255-268.

丸山孝彦(1979), 南部阿武涱高原の花耑岩類の Rb-Sr 同位体年代論。加納博教授記念論文集「日本列島 の基些」，523-558.

中川久夫，小川自子，鈴木羡身(1960)，仙台付近の第 四系枋よび地形（1）。第四紀研究，1，219-227。

中川光弘, 籍鳥 洋, 吉田武義 (1986), 青麻一恐火山 列：東北日本崛火山フロント。岩鉣, 81, 471-478.

Notsu, K. (1983) Strontium isotope composition in volcanic rocks from Northeast Japan arc. J. Volcanol. Geotherm. Res., 18, 531-548.

柴田 賢(1987), 阿武隈山地北端部, 丸森地域の花崗 岩類の Rb-Sr 全岩年代. 岩鉱，82，36-40.

Shibata, K. and Ishihara, S. (1979) Initial ${ }^{87} \mathrm{Sr} /{ }^{86} \mathrm{Sr}$ ratios of plutonic rocks from Japan. Contrib. Mineral. Petrol., 70, 381-390.

霜鳥 洋, 吉田武義, 青木謙一郎 (1983), 那省北帯・ 青麻火山の地球化学的研究. 東北大学核理研研究 報告, 16, 301-308.

富樫茂子, 吉田武義，青木謙一郎 (1986)，那須北帯. 第四紀恐山火山の微量元素. 東北大学核理研研究 報告，19，139-148.

Togashi, S., Shirahase, T. and Tamanyu, S. (1985), $\mathrm{Sr}$ isotopic geochemistry of voluminous rhyolite of the Tamagawa welded tuffs, related rocks and andesite of the young volcanics, in Hachimantai geothermal area, Northeast Japan. J. Volcanol. Geotherm. Res., 24, 339352. 